\title{
DEVELOPMENT OF A SLURRY-FED IN-CAN MELTER FOR NUCLEAR DEFENSE WASTE
}

PAUL D. D'ENTREMONT

H. CHARLES WOLF

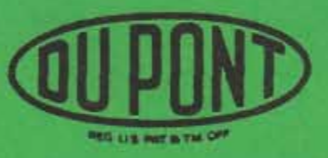

E. I. du Pont de Nemours \& Co. Savannah River Laboratory

Aiken, SC 29808 
DP -1662

Distribution Category: UC-70

\section{DEVELOPMENT OF A SLURRY-FED IN-CAN MELTER FOR NUCLEAR DEFENSE WASTE}

PAUL D. D'ENTREMONT

H. CHARLES WOLF

Approved by

J. E. Ortaldo, Research Manager

Waste Solidification Technology

Publication Date: December 1983

Issued by E. I. du Pont de Nemours \& Co. Savannah River Laboratory Aiken, SC 29808

PAEPARED FOR THE U S. DEPARTMENT OF ENERGY UNOEA CONTRACT DE-ACOQ-7ESRO0001 
- $2-$ 
A full-scale, nonradioactive process has been studied in which a slurry of waste sludge and glass formers is fed to a heaced can. Saturated steam is used to cool the off-gas. Inicial results show the concept to be technically adequate. 
$-4-$ 


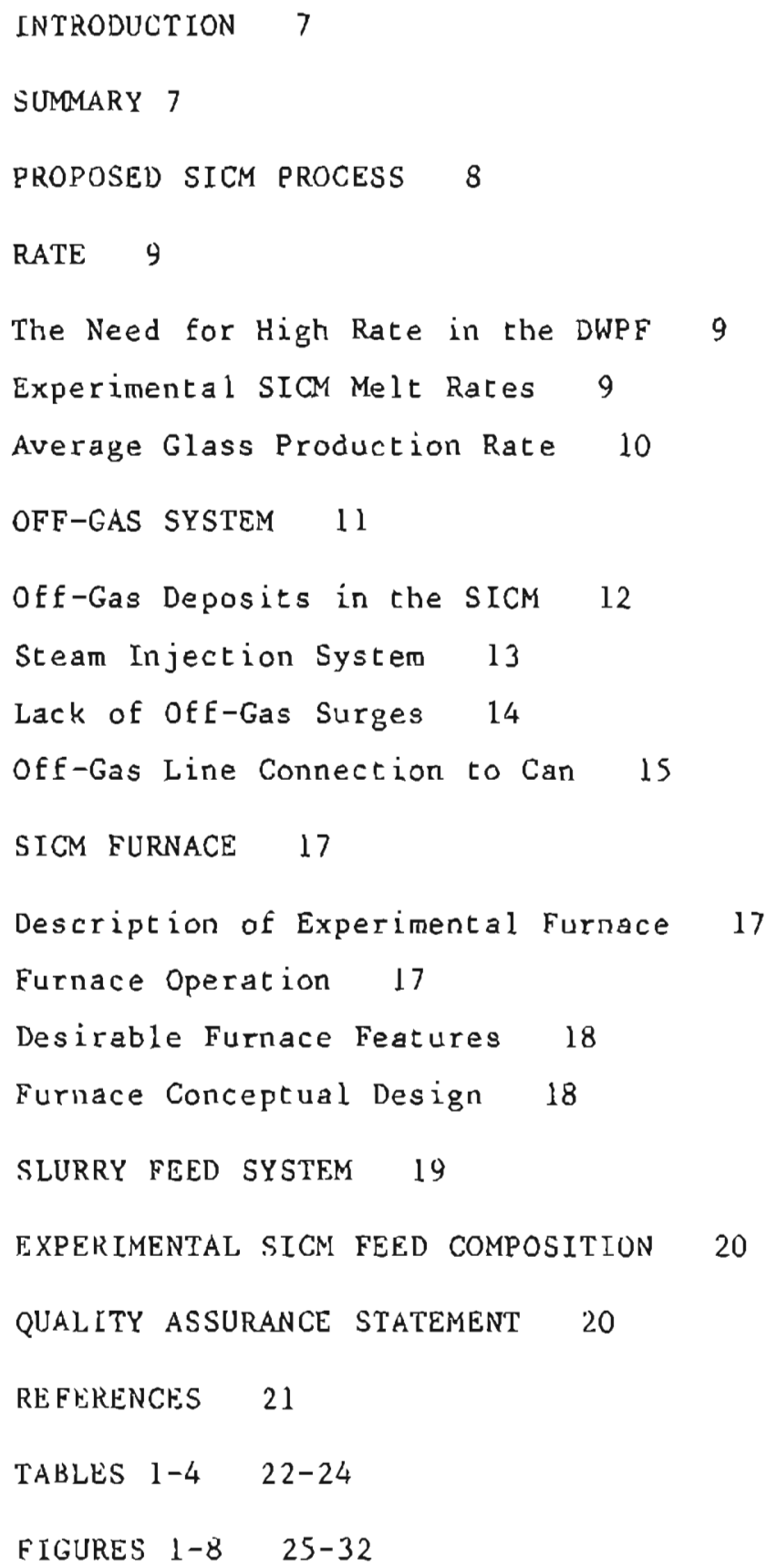


-6 - 


\section{INTRODUCTION}

The Savannah River Plant (SRP) has about 30 million gallons of high-level, radioactive, liquid waste stored in large waste ranks. This waste is a by-product of the production of nuclear defense materials at SRP. Plans are to build the Defense Wasce Processing Facility (DWPF) at SRP to convert this waste into solid form.

A key step in the planned DWPE process is the vitrification or glassmaking step, in which the radionuclides are incorporated in borosilicate glass. Two types of glass melters have been developed for this step. The planned melter design for the DWPF is a slurryfed, continuous, joule-heated melter. The backup melcer design is an in-can melter.

Previous plans were to dry and partially calcine the radioactive wate sludge before feeding it to the in-can melter. However, it was desirable to eliminate the drying step and feed the waste sludge as a liquid. Eliminating the drying step simplified the process and reduced the project cost.

At the Savannah River Laboratory (SRL), a full-scale in-can melter of the former dry-fed design ${ }^{1}$ was converted to slurry feeding by adding appropriate feed and off-gas systems. Five experimental runs were made with this process from August to December 1981. The purpose of this program was to demonstrate the basic process, determine key process variables such as rate and off-gas system requirements, and identify potential problems with long-term operation.

\section{SUMMARY}

Initial development work has been completed on a slurry-Fed In-Can Melter (SICM) process and has shown it to be a technically adequate alternative to joule-heated continuous melting, the reference process for the DWPF.

In the proposed SICM process, a stainless steel can is placed in a large tube furnace and heated to $1050^{\circ} \mathrm{C}$. Waste and glass formers (frit) are fed as an aqueous slurry which dries and melts. Feed is added continuously until the can contains approximately 3260 pounds of glass. The furnace is then maintained at $1050^{\circ} \mathrm{C}$ for 6 hours, to ensure that the glass is homogenous. The can is then cooled and removed to complete the cycle. Off-gases are cooled 
by the injection of a cooling medium and treated to remove contaminants.

A glass melting rate of up to $73 \mathrm{lbs} / \mathrm{hr}$ was demonstrated $\left(25 \mathrm{lbs} / \mathrm{hr}^{-} \mathrm{ft}^{2}\right)$. This is equivalent to an average processing rate of 40 to $54 \mathrm{lbs} / \mathrm{hr}$, depending on the time required for the nonfiil portions of the cycle. The SICM glass melting rate is high for a slurry-fed process because the melt surface is exposed to the $1050^{\circ} \mathrm{C}$ heat of the canister walls above the melt surface.

Injection of low temperature steam into the off-gas line was shown to be an excellent method of cooling the off-gas. Proper cooling of the off-gas was essential to prevent plugging of the off-gas line. Steam cooling is the simplest system which will adequately cool the SICM off-gas line to prevent deposition.

No further experiments are planned on the SICM at the Savannah River Laboratory. Future DWPF glass melter development will focus exclusively on the reference continuous melter.

\section{PROPOSED SICM PROCESS}

A. two-foot diameter, $304 \mathrm{~L}$ stainless steel can is placed in a large tube furnace (Figure 1). If the melter has been in continuous service, the furnace will still be warm from the previous can. The combination off-gas/feed line is connected to the can, a slight negative pressure is pulled on the can, then the Eurnace top is closed. The annulus between the can exterior and the furnace is flooded with argon, and the furnace is heated to $1050^{\circ} \mathrm{C}$. The remperature is limited to $1050^{\circ} \mathrm{C}$ because, above this temperature, the mechanical strength of $304 \mathrm{~L}$ stainless steel is not adequate for the process.

As the can is heated, the off-gas temperature will increase. This is because argon will leak past the connection of the can and off-gas line and be heated in the can interior, then flow up the off-gas line. When the off-gas temperature passes $450^{\circ} \mathrm{C}$, the offgas temperature controller will automatically start introducing steam into the entrance of the off-gas line to maintain the off-gas remperature at $450^{\circ} \mathrm{C}$. Feed starts when the can reaches $1050^{\circ} \mathrm{C}$. The feed is $40 \%$ total solids, with a frit/waste ratio of up to 65/35. The feed rate is 0.3 to $0.5 \mathrm{gpr}$. The slurry falls to the melt surface, ories, and melts. Feed nozzle plugs, which may form are periodically cleared with a feed nozzle cleaning device. (Additional development work may identify other methods to eliminate nozzle pluggages.)

The can fills with 3260 pounds of glass in 44 hours (73 lbs/hr average fill rate). The furnace is raintained at $1050^{\circ} \mathrm{C}$ for six 
DEVELOPMENT OF A SLURRY-FED IN-CAN MELTER

FOR NUCLEAR DEFENSE WASTE

\section{INTRODUCTION}

The Savannah River Plant (SRP) has about $30 \mathrm{million}$ gallons of high-level, radioactive, liquid waste stored in large waste tanks. This waste is a by-product of the production of nuclear defense materials at SRP. Plans are to build the Defense Waste Processing Facility (DWPF) at SRP to convert this waste into solid form.

A key step in the planned DWPF process is the vitrification or glassmaking step, in which the radionuclides are incorporated in borosilicate glass. Two types of glass melters have been developed for this step. The planned melter design for the DWPF is a slurryfed, continuous, joule-heated melter. The backup melcer design is an in-can melcer.

Previous plans were to dry and partially calcine the radioactive waste sludge before feeding it to the in-can melter. How ever, it was desirable to eliminate the drying step and feed the waste sludge as a liquid. Eliminating the drying step simplified the process and reduced the project cost.

At the Savannah River Laboratory (SRL), a full-scale in-can melter of the former dry-fed design l was converted to slurry feeding by adding appropriate feed and off-gas systems. Five experimental runs were made with this process from August to December 1981. The purpose of this program was to demonstrate the basic process, detenoine key process variables such as rate and off-gas system requirements, and identify potential problems with long-term operation.

\section{SUMMARY}

Initial development work has been completed on a slurry-Fed In-Can Melter (SICM) process and has shown it to be a technically adequate alternative to joule-heated continuous melting, the reference process for the DWPF.

In the proposed SICM process, a stainless steel can is placed in a large tube furnace and heated to $1050^{\circ} \mathrm{C}$. Waste and glass formers (Erit) are fed as an aqueous slurry which dries and melts. Feed is added continuously until the can contains approximately 3260 pounds of glass. The Eurnace is then maintained at $1050^{\circ} \mathrm{C}$ for 6 hours, to ensure that the glass is homogenous. The can is thencooled and removed to complete the cycle. Off-gases are cooled 
by the injection of a cooling medium and treated to remove contaminants.

A glass melcing rate of up to $73 \mathrm{lbs} / \mathrm{hr}$ was demonstrated (25 lbs/hr-ft ${ }^{2}$ ). This is equivalent to an average processing rate of 40 to $54 \mathrm{lbg} / \mathrm{hr}$, depending on the time required for the annfili porcions of the cycle. The SICM glass melting rate is high for a slurry-fed process because the melt surface is exposed to the $1050^{\circ} \mathrm{C}$ heat of the canister walls above the melt surface.

Injection of low temperature stean into the off-gas line was shown to be an excellent wethod of cooling the off-gas. Proper cooling of the off-gas was essential to prevent plugging of the off-gas line. Steam cooling is the simplest systew which will adequately cool the SICM off-gas line to prevent deposition.

No further experiments are planned on the SICM at the Savannah River Laboratory. Future DWPE glass melter development will focus exclusively on the reference continuous melter.

\section{PROPOSED SICM PROCESS}

A two-foot diameter, $304 \mathrm{~L}$ stainless steel can is placed in a large tube furnace (Figure 1). If the melter has been in continuous service, the furnace will still be warm from the previous can. The cumbination off-gas/feed line is connected to the can, a slight negative pressure is pulled on the can, then the furnace top is closed. The annulus between the can exterior and the furnace is flooded with argon, and the furnace is heated to $1050^{\circ} \mathrm{C}$. The temperature is limited to $1050^{\circ} \mathrm{C}$ because, above this temperature, the mechanical strength of $304 \mathrm{~L}$ stainless steel is not adequate for the process.

As the can is heared, the off-gas temperature will increase. This is because argon will leak past the connection of the can and off-gas line and be heated in the can interior, then flow up the off-gas line. When the off-gas temperature passes $450^{\circ} \mathrm{C}$, the offgas temperature controller will automatically start introducing steam into the entrance of the off-gas line to maintain the off-gas cemperature at $450^{\circ} \mathrm{C}$. Feed starts when the can reaches $1050^{\circ} \mathrm{C}$. The feed is $40 \%$ total solids, with a Erit/wasce ratio of up to $65 / 35$. The feed rate is 0.3 to $0.5 \mathrm{gpm}$. The slurry falls to the melt surface, dries, and melts. Feed nozzle plugs, which may form are periodically cleared with a feed nozzle cleaning device. (Additional development work may identify other methods to eliminate nozzle pluggages.)

The can fills with 3260 pounds of glass in 44 hours $(73 \mathrm{Lbs} / \mathrm{hr}$ average fill rate). The furnace is maintained at $1050^{\circ} \mathrm{C}$ for six 
hours after feed shutoff. This allows the relatively cool material in the top $1 / 2$ to $1-1 / 2$ feet of the melt at feed shutdown to hear up to $1050^{\circ} \mathrm{C}$ and gives the glass time to horogenize. After six hours, the furnace is shut off and the can is cooled. When the can reaches the proper removal temperature, the furnace top is opened and the off-gas line is disconnected from the can. A temporary plug is placed in the can nozzle and the can is removed from the furnace. The furnace is now ready for a new can to begin the cycle again.

The SICM process differs from other slurry-fed, in-can melter processes in that the entire can is heated. In some slurry-fed, in-can melter processes developed for power reactor waste (for example, the HARVEST process developed in Great Britain), the can wall above the melt line is kept cooll to limit the temperature of the off-gas and the melt surface. In the DWPF SICM process, the entice can is heated, and the off-gas is cooled by steam injection. This results in a higher melt rate.

\section{RATE}

The Need for High Rate in the DWPF

A key objective of the SICM experimental program was to develop a relatively high rate process. A high rate for the DWPF melter is needed because of the large volume of waste at SRP, about 30 million gallons, which must be processed.

The goal of the DWPF is co solidify the present inventory of waste at SRP plus waste from current production within 20 years after startup. In other words, after 20 years the DWPE should be processing only current waste from SRP, with only a constant fiveyear inventory of waste to permit decay of short-lived radionuclides in the waste before processing. To meet this goal, a glass production rate goal of $228 \mathrm{lbs} / \mathrm{hr}$ has been established for the DWPF melter. Four to six SICM units would be required to meet this goal.

\section{Experimental SICM Melt Rates}

SICM melt rates were studied in an experimental melter at SRL with 2-foot diameter stainless steel cans. The melt rates varied from $29 \mathrm{lbs} / \mathrm{hr}$ to $73 \mathrm{lbs} / \mathrm{hr}$ in five experimental runs (Table 1), with a furnace temperature of $1050^{\circ} \mathrm{C}$. The melter was fed a conservatively low rate in the first runs, and the feed rate was increased in succeeding runs as it became apparent that the melter could process the higher rates. 
The highest glass melt rate demonstrated was $73 \mathrm{lbs} / \mathrm{hr}$ in the fourth run (a melt flux of $25 \mathrm{lbs} / \mathrm{hr}-\mathrm{ft}^{2}$ ). This rate was maincained despite the failure of two-thirds of the heaters which heat the top three feet of the can. This indicates that $73 \mathrm{lbs} / \mathrm{hr}$ is a conservative estimare of the rate achivable in a 2 -foot diameter SICM can.

\section{Average Glass Production Rate}

The average SICM rate depends on the time required to complete each part of the SICM cycle. The SICM cycle consists of five disrinct periods. They are as follows:

1. Melt period.

2. Bake-out period (the time from the end of the melt period until the furnace is shut off).

3. Cooldown period.

4. Can change period.

5. Heatup period.

Each of these periods was studied in an experimental furnace at SRL. The time required to complete each period was estimated as follows (Table 2):

- The melt period required 44 hours, corresponding to a rate of $73 \mathrm{lbs} / \mathrm{hr}$ in Filling a 3260-pound can.

- The bake-out period required 6 hours. About 2 hours at temperature was required for the entire contents of the can to heat up to $1050^{\circ} \mathrm{C}$. The remaining 4 hours were required to ensure that the glass was homogeneous. (More or less time may be required, depending on waste and frit composition.)

- The cooldown period required 4 to 20 hours. The time required for the cooldown depends on what temperature is permissible to remove the can from the furnace. If a $700^{\circ} \mathrm{C}$ can wall temperature limit is used, 4 hours of cooling are required. Removal of a can at $700^{\circ} \mathrm{C}$ has been demonstrated at Pacific Northwest Laboratory. 2 However, current guidelines for design of the DWPF call Eor a maximum glass centerline temperature of $600^{\circ} \mathrm{C}$ before lifting. This is a much more conservative limit, requiring a 20-hout cooldown period (Figure 2).*

* Data on can cooldown was supplied by G. W. Becker. The data was obtained in Run 7 of the dry-fed in-can melter program at SRL. 1 The dry-fed in-can melter dara also applies to the SICM because the can geometry and method of cooldown are the same for both melters. 
- The can change period was estimated to require 2 hours. This period was not studied in the experimental melter. However, the accuracy of this estimate is not essential because the can change period is short compared to the rest of the SICM cycle.

- The heatup period required 4 to 9 hours. The variation of the period is also a function of the permissible temperature limit for can removal because the heatup starts at the same remperature that the can is removed.

Thus, the total cycle time for a reference can was estimated to be between 60 and 81 hours. This is equivalent to an average rate of 40 to $50 \mathrm{lbs} / \mathrm{hr}$. Therefore, 4 to $6 \mathrm{sLCM}$ melters would be required to meet the DWPF glass production rate, assuming equal reliability of the DWPF process with the SICM melter or the continuous melter planned for the DWPF.

The spread in the estimated cycle times was caused by the uncertainty on the permissible temperature limit for can removal. This limit affects both the estimated heatup and cooldown times. Therefore, selection of the permissible temperature limit for removing a can has a major impact on the SICM cycle time and average rate.

The selection of this limit also has important safety considerations in a can-drop accident, and no experimental data exists for can drops at elevated temperature. Further work would be required to support a relatively high temperature limit, such as the $700^{\circ} \mathrm{C}$ can temperature limit recommended by PNL.

\section{OFF-GAS SYSTEM}

The SICM program demonstrated that a steam injection cooling system coupled with proper insulation of the off-gas line dramatically reduces the potential for off-gas line buildups.

The composition of the SICM off-gas is mostly water vapor and noncondensable gases - primary oxygen, carbon monoxide, and carbon dioxide, plus air and argon that leak into the off-gas line. Small quantities of particulares (frit and waste sludge particles) and semivolatile materials evaporated from the molten glass are also found in the off-gas. The purpose of a melter off-gas system is primarily to remove the particulates and semivolatiles, which contain virtually all of the radioactivity in the off-gas.

The SICM off-gas composition would be very similar to the off-gas from a DWPF continuous melter. Therefore, a similar offgas system could be employed. Plans for the DWPF continuous melter are to send the hot off-gas from the melter to an ejector venturi scrubber. In the scrubber, the oft-gas is intimately mixed with 
cold water. This cools the gas, condenses most of the water vapor, and traps some of the particulates and semivolatiles. The cooled gas from the scrubber is then sent to several additional stages of decontamination before being released to the armosphere.

Off-gas work in the SICM experimental program concentrated primarily on the hot off-gas line between the melter and the ejector venturi scrubber. Past the ejector venturi scrubber, any offgas system developed for the reference DWPF continuous melter would probably be acceptable for the SICM. This development effort was therefore not duplicated in the SICM program. However, the high temperature of the SICM off-gas poses special problems in the hot off-gas line. The SICM off-gas at the melter is 900 to $1000^{\circ} \mathrm{C} \mathrm{com-}$ pared to a continuous melter off-gas temperature of about 520 to $800^{\circ} \mathrm{C}$.

Previous experience with continuous melters had shown that the particulates and semivolatiles tended to cause plugging problems when they deposited in the off-gas lines. In the ccntinuous melter experiments, the particulates began to deposit when the frit became sticky due to the off-gas temperature being above the frit softening point of $475^{\circ} \mathrm{C}$. The semivolatiles tended to condense out and deposit as the temperature decreased. Therefore, maintaining the off-gas slightly below the frit softening temperature was desirable.

\section{Off-Gas Deposits in the SICM}

Plugs in the hot off-gas line between the melter and the ejector venturi were anticipated to be a major problem.

The first SICM experiment (SICM-1) demonstrated the need for an off-gas cooling system. There was no means of cooling the gas stream for this run. As a consequence, the off-gas temperature 3 feet downstream of the can was 600 to $850^{\circ} \mathrm{C}$. This was much higher than the target of $450^{\circ} \mathrm{C}$; and deposits, projecting up to $3 / 4$ inch from the pipe walls, formed in the off-gas line (Figure 3). Several clumps formed after the first bend, and a second deposit was located after the first $90^{\circ}$ bend. Both of the deposits formed only on the less than vertical surfaces of the pipe. These deposits formed in the disturbed flow regions following the bends where the sticky frit particles in the off-gas settled from the off-gas and stuck to the pipe.

The worst deposit formed 35 feet downstrean of the melter at the point where a 4 -inch flange had inadvertently been left uninsulated. The deposit filled the entire 6-inch off-gas line indicating that a cold spot greatly accelerates deposits. The deposit was most likely the combination of sticking frit and semivolatile condensation. 
Very little accumulation in the off-gas line was discovered other than in these three areas. A very thin glassy film, less than 0.01 inch, was found in the first two feet of off-gas piping. Elsewhere in the line, a light nonglassy dust was found, mostly on the bottom of the piping. The light deposits also tended to form only where particles in the off-gas would fall by gravity to the piping surface.

\section{Steam Injection System}

To alleviate the deposit problem, the off-gas temperature was controlled during SICM-2, SICM-3, SICM-4, and SICM-5 by the injection of saturated steam into the off-gas line, 3 feet downstream of the melter. Figure 4 is a schematic of the system that supplied steam to the off-gas line. The steam was supplied by a 150 psig steam header and regulated by an automatic valve controlled by an operator in the SICM control room. The temperature of the off-gas downstream of the steam injection point was measured using a thermocouple which sent a signal back to the control room. The operator running the SICY monitored the temperature and adjusted the stean flow as necessary to maintain the desired temperature of $440^{\circ} \mathrm{C}+25^{\circ} \mathrm{C}$. A condensate valve just ahead of the flow regulating value prevented liquid water from entering the melter.

This system was found to be en excellent method to control the off-gas temperature (Figure 5) and was successful in eliminating deposits. The steam injection system cooled the gas from $900^{\circ} \mathrm{C}$ at the can top to any desired temperature and was used to maintain the off-gas temperature 3 feet downatream of the canister at $440^{\circ} \mathrm{C}$. The off-gas temperature remained steady at a constant feed rate and could be easily maintained by manually adjusting the steam flow rate every 10 to 15 minutes.

The system also reduced the drop in temperature of the off-gas as it flowed down the off-gas line (Table 3 and Figure 5). This was because of the increased gas flow. A small drop is desirable because this raises the remperature at the end of the line, decreasing the chances of semivolatile deposition.

While the steam injection system was in operation, no noticeable deposits were found in the off-gas line downstream of the steam injection point. Also the line was free of the settled dust found in the first run. Although the lack of deposits is believed to be primarily due to the lower off-gas temperature, it is also partly due to the increased off-gas velocity. The addition of the steam greatly increases the total gas flow rate in the off-gas line, which would reduce the amount of particulate settling. The deposits found in SICM-l, when no steam injection was used, were found only in locations where the particles would have settled on to the pipe. 
Steam injection cooling is the simplest system that will adequately cool the SICM off-gas and successfully eliminate off-gas line deposits. The main disadvancage of steam cooling is that it increases the water load to the melter off-gas system. The SICM requires 1.7 to 2.2 pounds of steam per pound of uncooled SICM offgas. This is 330 to $440 \mathrm{lbs} /$ hour of additional water per melter which must be processed in the DWPF. The required steam rate is large because of the high SICM off-gas temperature.

Further development work might reduce the water load, possibly through the use of a water spray systen or air injection. PNL has experimented with water spray systems for cooling continuous melter off-gases. The water load for the water systems is less than the load for the steam, but the method of injection is critical. Deposits form quickly if water impinges on the walls of the off-gas Iine. The design of a water spray system is more critical, and would probably require more maintenance than a steam injection system. Air injection would also decrease the water load relative to steam, but it may pose other complications.

Steam injection cooling may be used for cooling off-gases from other waste glass melters, especially continuous mel.ters. Because the off-gas temperature at the melter exit is much lower in a continuous melter than in a SICM, the amount of cooling steam required is much less. Steam cooling is cherefore even more attractive for a continuous melter than a SICM. Steam cooling is the simplest and least troublesone method to cool the off-gas when an increased water load can be accommodated.

\section{Lack of OEE-Gas Surges}

The SICM showed very little surging behavior of the off-gas flow rate. At a constant feed rate, the off-gas flow rate exiting the melter never differed from the average off-gas flow rate by more than $10 \%$.

Surging behavior of the off-gas can be a problem in a liquid fed melter because it makes the off-gas system roure difficult to design. The system must be designed large enough to handle the largest routine off-gas surge. Also, the off-gas pressure control system must respond quickly enough to handle the fast rise and fall of an off-gas surge.

Surging behavior, although not observed, was anticipated to be a possible problem with the SICM because of the high temperature of the can. If a large liquid inventory developed in the can, the high temperature could cause high heat transfer rates, and consequently high evaporation rates. Specifically, two scenarios were 
of concern: 1) a pocket of liquid feed could become trapped in the pile of dried but unmelted feed winch rides on top of the glass. If this liquid feed were to fall chrough a chance crack in the dried feed and meet $1050^{\circ} \mathrm{C}$ glass, this could suddenly increase the of E-gas flow rate. 2) A bridge of dried but unmelted feed could form over the entire melt surface. If this bridge sealed the entire cross sectional area of the can and some liquid were trapped beneath it, the pressure underneath the bridge would build up until the bridge ruptured, which would very sharply increase the off-gas flow rate.

This is surprisingly low because heat transfer calculations indicate that to support evaporation at the feed rate abserved in SICM-4 ( 73 pounds/hour glass rate) would require coverage of almost the entire $3 \mathrm{ft}^{2}$ cross-section area of the can. Evidently, much of the heating and drying of the slurry occurs as it falls to the melt surface. During its descent, the slurry is bached in almost a $1050^{\circ} \mathrm{C}$ black-body radiation field. Coverage of greater than $20 \%$ could have been accomplished in the SICM experiments by feeding the can much faster. However, when the can was overfed, the dried unmelted feed pile started to grow. This would have required a very long bake time. Therefore, chere was no advantage to a higher slurry coverage.

A small amount of bridging activity was observed, but the bridges were never observed to cover more than $10 \%$ of the melced surface. When small bridges did form, the hot can walls quickly melted the feed where it was in contact with the wall and caused the bridge to collapse. The small liquid inventory and the high can temperature made the formation of bridges happen only rarely.

Also, no cendency was observed for the slurry to become trapped under the dried feed. The slurry would generally fall on to the melt surface and then flow away from the impact point, forming a volcano-like mound. The location of the feed impact would frequently wander, probably because pieces of dried feed would forn on the feed nozzle tip then fall off, diverting the stream one way then the other. The feed would therefore move away from its present mound and start forming a new one elsewhere on the melt surface. The old mound would then quickly melt away. The cold laver was therefore a constantly changing environment, not the relarively stable "cold cap" often seen in liquid-fed cont inuous melters.

Off-Gas Line Connection to Can

Perhaps the greatest challenge in the SICM is the connection of the can to the off-gas line. This connection must be made and 
broken once each cycle. The design of the connection and design of the off-gas line within a few feet of the connection is critical because:

1. The connection is prone to off-gas line pluggage because it is the transition between the hot can and the much cooler off-gas line.

2. The connection must resist corrosion by the off-gas or be protected from the off-gas.

3. The connection must be compatible with later processing of the can.

The connection between the can and the off-gas line used in Runs SICM-1 through SICM-4 worked well. This connection, which is the off-gas line extending through a hole in the can top plate, was used because it. was simple and inexpensive. Initial SICM runs were intended to investigate other parts of the SICM system. Less than 0.01 inch of black glassy deposits formed in the bottom three feet of the off-gas line during these runs. The very small anount of deposits was surprising because the line was not cooled in this region and was probably $800^{\circ} \mathrm{C}$ to $1000^{\circ} \mathrm{C}$; therefore, considerable deposits were expected from sticking of softened frit. A possible explanation for the small amount of deposits is that material deposited, but the temperature was high enough to melt the deposit and cause it to drop back. into the canister.

In the final SICM experimental run, deposits plugged the offgas line near the can. This run was the first and only attempt to use a reference DWPF can in the SICM. The bottom 24 inches of the off-gas line which formerly entered a 6-inch diameter hole was redesigned to fit the smaller 5-inch diameter reference nozzle (Figure 6). This left an annulus of only $1 / 2$ inch through which the off-gas could pass because the feed tube assembly was located in the center of the off-gas line. Although this was not considered an optimum arrangement, it was judged adequate because of the lack of deposits in previous runs. The off-gas annulus filled with glassy deposits 2 inches above the can top. The deposits must be related to the different can top and redesigned off-gas line, but no good explanation exists for the greatly increased deposits.

More work is needed to better understand what happens at the connection between the can and off-gas line and to develop a connection that will fit with a reference nozzle. The best option at this time appears to be injection of the off-gas cooling medium into the base of the off-gas line right at the can connection. Thus, the off-gas line would have no uncooled section, eliminating the frit sticking problem. Several methods to accompli.sh this are 
being considered for the DWPF continuous melter. Any of these methods would be candidates for the SICM.

\section{SICM FURNACE}

\section{Description of Experimental Furnace}

The furnace used in the SICM experimental work is a resistance heared rube furnace (Figure 7). The can is supporced in the center of the furrace with a refractory pedestal. A tube and sightglass are attached to the experimental cans to permit viewing of the melting process during a run. Surrounding the can are 54 electric heaters. The heaters are made of Kanthal (Kanthal Corp.) A-l alloy with ceramic backing. The heaters are organized in nine cylindrical heating zones. Each zone contains a ring of heaters 12-inches tal1, 39 inches inside diameter, with 6 heaters. Each heater occupies $60^{\circ}$ of the ring. The entire zone is operated as a unit, i.e. power goes to all 6 heacers or none.

The power to each heating zone is controlled by a proportional controller, which responds to a thermocouple positioned in the space between the heating ring and the can. Also, a second high limit controller in each zone responds to a thermocouple $180^{\circ}$ from the control thermocouple. The maximum power to each zone is $30 \mathrm{~kW}$. Thus, maximum power to the entire furnace is $270 \mathrm{~kW}$.

The heaters are surrounded by insulation which is contained in a rectangular steel shell 138 -inches tall and 66 inches wide and deep. In the rop of the furnace is a refractory plug, with a hole in the center through which the feed and off-gas assembly passes.

The furnace contains an air cooling syster to cool the full cans. An air blower and ducts can supply air at up to $300 \mathrm{cfm}$ to the bottom of the furnace. The air is released into the furnace at 4 points equally spaced around the support pedestal. Ducts exiting from the top of the furnace can exhaust the hot air from the top of the furnace. Dampers are provided in the air supply and exhaust ducts to prevent thermal drafts while the furnace is being heated.

The off-gas from the can is sent to an off-gas system designed for an experimental DWPF continuous melter. Except for the off-gas line up to the ejector venturi scrubber, this system was not studied in the SICM experimental program.

\section{Furnace Operation}

To start an experimental run, the air supply and exhaust dampers were closed. Then the setpoint for each of the zone 
controllers was raised $50^{\circ}$ every 20 minutes, until each reached $1050^{\circ} \mathrm{C}$. Once the Eurnace reached $1050^{\circ} \mathrm{C}$, feed to the can was started. The setpoints for each controller were lett at $1050^{\circ} \mathrm{C}$ for che duration of the run.

To cool the furnace and can, the power to the heaters was shut off, both dampers were opened, and air was blown through the furnace with the blower. The amount of air flow could be regulated by partially closing the dampers.

\section{Desirable Furnace Features}

The following features are desirable in a DWPF SICM furnace:

- Independant temperature controlled heating zones, each supplying heat to 1 to 2 vertical feet of the furnace similar to the heat control strategy used in the experimental furnace. This is needed because the heat in a SICM furnace is consumed mainly above the melt surface, and thus, the heat distribution needed will change as the melt surface rises during the run.

- An argon atmosphere surrounding both the can and the connection of the can and off-gas line. This protects the can from oxidation. The experimental furnace was not air tight. Therefore, the stainless steel cans used in those experiments oxidized severely. In an air atmosphere, the excent of the oxidation is such that oxide flakes off, forming a spall. In SICM runs with an air atmosphere, 16 to 42 pounds of spall were formed. However, small-scale experiments at PNL have shown that the oxidation of stainless steel can be reduced to that of Inconel ${ }^{\star}$ (Huntington Alloys, Inc.) when placed in an argon atmosphere of sufficiently low oxygen content. 2

- Secondary containment around the can, to contain a spill in the unlikely event that a can is breached in the furnace.

- Forced air cooling to cool a can rapidly. This reduces the total SICM cycle time and also minimizes the time the glass spends in the temperature region of East devitrification, 800 to $1000^{\circ} \mathrm{C}$.

\section{Furnace Conceptual Design}

A proposed conceptual design of a SICM furnace is shown in Figure 8 . The can is surrounded wich a slightly larger retort of a high temperature alloy. The retort is removable from the furnace. An argon atmosphere is maintained in the annulus between the can 
and retort. The retort is heated by induction coils which are separated from the retort with insulation to keep them cool.

The retort could also be heated with resistance heating elements inside the insulation, but these would probably need to be replaced more frequently than induction heaters. The power to each vertical foot of the coils is independantly controlled to maintain the temperature of that foot of the retort at $1050^{\circ} \mathrm{C}$. The recort also serves as a secondary containet in the unlikely event of a can rupture.

After filling, the can is cooled by blowing air through the annulus between the retort and first layer of insulation. The rate estimates given in the section on average glass production rate assume that the can is quickly cooled with about $300 \mathrm{cfm}$ of air, as the SRL SICM was cooled. Of course fast cooling would shorcen the life of the furnace due to thermal shock on the furnace refractory and other parts. Therefore, deciding the rate of cooldown will be a trade-off of process rate and furnace life.

A properly designed retort furnace might also perrit contact maintenance of the furnace. The area above the furnace would likely become contaninated quickly because it would be exposed to the feed slurry and off-gas connections and open cans would probably be handled in this area. Therefore, maintenance in this area would likely have to be done remotely. However, a concrete floor could be placed near the top of the furnace, as shown in Figure 8 . The retort would then tend to prevent the area below the concrete floor and outside of the retort from becoming contaminated. If the retort were removed and a slab of shielding material were placed on top of the furnace, the furnace would probably be low enough in contamination and radiation to permit contact maintenance.

\section{SLURRY FEED SYSTEM}

The experimental SICM was fed a slurry of simulated waste and frit in water. The feed rate was controlled using a peristaltic pump with plastic tubing, which metered the slurry into the SICM feed nozzle.

With the exception of the feed nozzle, any feed system suicable for the DWPF continuous melter would probably be acceptable for the SICM. The peristaltic pump used in the experimental work would not be suitable, because the radiation levels of the actual waste would quickly degrade the plast ic tubing. However, several methods of feeding the DWPF continuous melcer are being investigated and developed at SRL. Any of these methods which can handle the abrasive slurry feed at 0.2 to 1.0 gpin is acceptable for the SICM. 
Further development work is needed to ensure that the feed nozzle is kept open. The SICM feed nozzle is located at the can centerline a few inches into the can. At this point, the nozzle tip is exposed to the intense heat from the $1050^{\circ}$ can. The feed assembly is a pipe-within-a-pipe arrangement with cooling water designed to keep the slurry cool until it exits the nozzle. However, the heat from the can ories slurry at the tip of the nozzle, occasionally forming plugs.

In the experimental SICM, the plugs were easily cleared with a 0.125 -inch rod (the nozzle opening was 0.2 inches). A mechanical device which would periodically rod this opening should be sufficient to keep the feed line clear. But better methods to keep the line open should be investigated, such as water or steam sparging.

\section{EXPERIMENTAL SICM FEED COMPOSITION}

The feed composition used in the high rate Run SICM-4 is shown in Table 4. This simulated waste composition is representative of the average anticipated SRP waste composition, which is called "Stage I simulated waste" at SRL. The glass frit was the Frit 140 composition. This frit was developed at SRL specifically for in-can melting. The composition is very similar to Frit 131, a frit developed for continuous melting of SRP waste. The simulated waste and frit were mixed in the ratio $35 / 65$. The waste and frit comprized $41 \%$ total solids in water.

\section{QUALITY ASSURANCE STATEMENT}

The work described in this report covered the time period August to December 1981. The work was performed according to written procedures to ensure safe and proper operation. All documentation was maintained either in registered laboratory notebooks or data files. After analysis of the data from each run, an internal memo was the main document of record. Measuring instruments were calibrated by trained personnel with certified standards. 
1. G. W. Becker, Jr. Developwent of the In-Can Melting Proceas for Vitrification of Savannah Biver Plant Haste. Presented at the meeting of the Nuclear Division - American Ceramic Sociery, October 26-29, 1980.

2. D. E. Larson, Edicor. Sprag Calciner/In-Can Melter HighLevel Usate Solidification Technical Manual. PNL 3495, Pacific Northwest Laboratory, Richland, Washingcon (September 1980). 
TABLE 1

Experimental Glass Melt Rates

\begin{tabular}{|c|c|c|c|c|}
\hline $\begin{array}{c}\text { Experimental } \\
\text { Run } \\
\end{array}$ & $\begin{array}{l}\text { Total Run } \\
\text { Time, hrs } \\
\end{array}$ & $\begin{array}{l}\text { Total Feed } \\
\text { Time, hrs }\end{array}$ & $\begin{array}{l}\text { Total Glass } \\
\text { Produced, lbs }\end{array}$ & $\begin{array}{l}\text { Average } \\
\text { Mele Rate, } \\
\text { lba/hr }\end{array}$ \\
\hline SICM-1 & 39.93 & 30.58 & 1147 & 29 \\
\hline SICM-2 & 78.5 & 73.5 & 3000 & 38 \\
\hline $\mathrm{SICM}-3$ & 46.2 & 31.6 & 3270 & 71 \\
\hline SICM-4 & 42.70 & 38.32 & 3132 & 73 \\
\hline$S 1 C M-5$ & 17.75 & 9.40 & 894 & $\therefore$ \\
\hline
\end{tabular}

* The rate was determined by dividing the total pounds of glass produced by the total run cime. Total run time is the elapsed time from start of feeding to termination of feed. This does not include bake-out, can change, or heat up.

* The rate in SICM-5 was limited for much of the run by the restricted off-gas line. The maximum rate in the SICM was demonstrated in SICM-4.

TABLE 2

Galculation of SICM Average Rate

Mele Rate: $73 \mathrm{lbs} / \mathrm{hr}\left(25 \mathrm{lbs} / \mathrm{hr}_{\mathrm{ft}} \mathrm{fl}^{2}\right)$

Cycle step

Melt ( 3260 lba of glass)

Bake

Cooldown

Can Change

Heatup

TOTAL

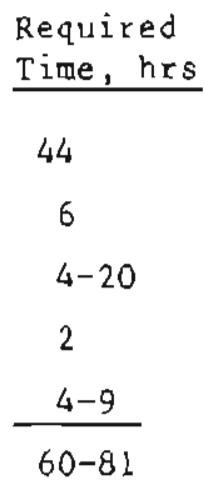

Average SICM rate, $100 \%$ attainment: $40-541 \mathrm{bs} / \mathrm{hr}$

Conclusion: 4-6 SICM melters for DWPE goal, $228 \mathrm{lbs} / \mathrm{hr}$ 
TABLE 3

SICM Cooling System Data

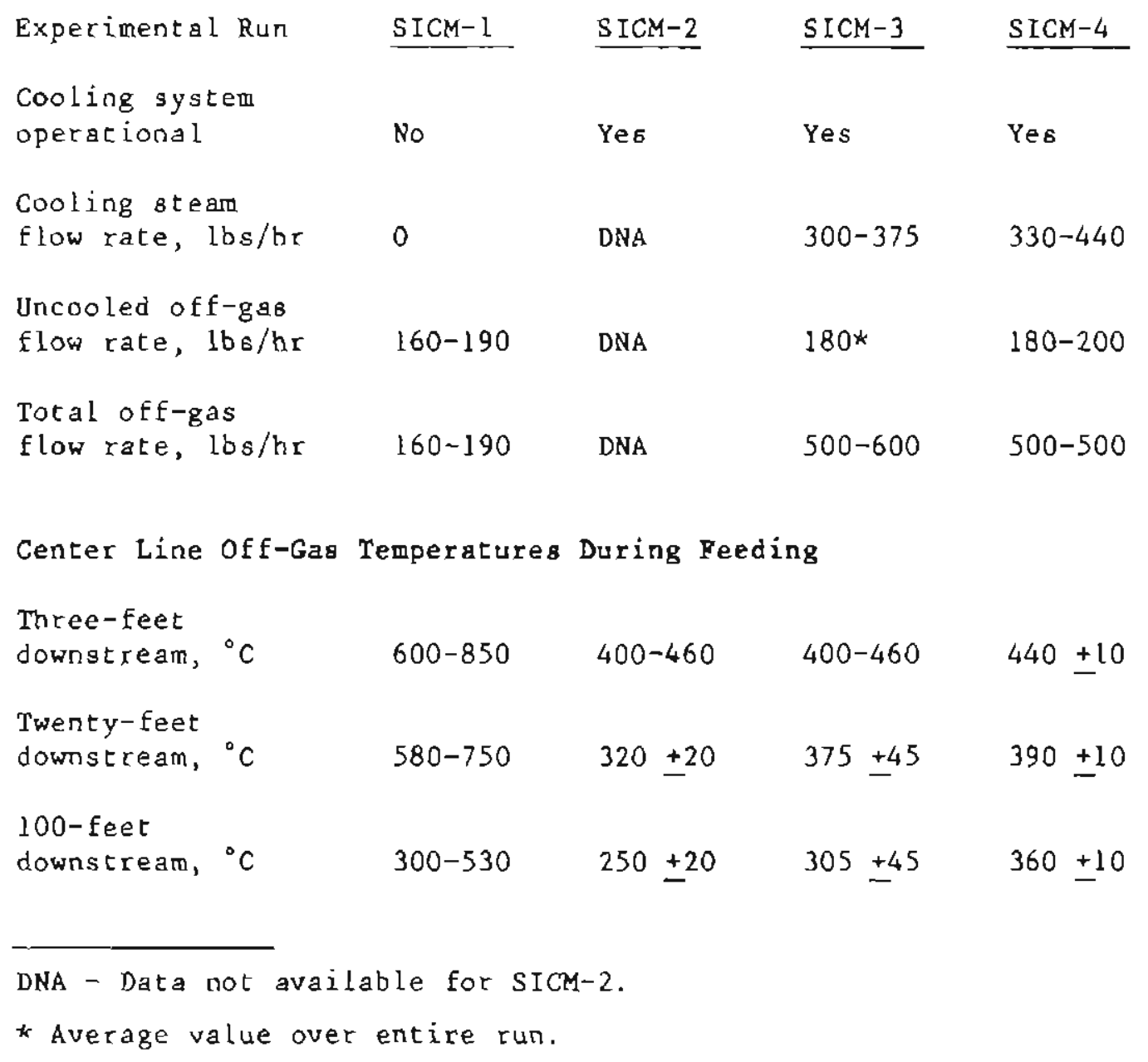


TABLE 4

SICM-4 Peed Compositions

Frit 140

Stage 1 Sludge

Component We $\%$

Component Wt

$\mathrm{SiO}_{2} \quad 60$

$\mathrm{Fe}(\mathrm{OH})_{3}$

$\mathrm{B}_{2} \mathrm{O}_{3}$

$\mathrm{MnO}_{2}$

11

$\mathrm{Na}_{2} \mathrm{O} \quad 14$

$\mathrm{CaCO}_{3}$

8

$\mathrm{Li}_{2} \mathrm{O}$

5

$\mathrm{Ni}(\mathrm{OH})_{2}$

3

$\mathrm{MgO}$

2

$\mathrm{Al}(\mathrm{OH})_{3}$

21

$\mathrm{Al}_{2} \mathrm{O}_{3} \quad 0.6$

Coal

0.1

$\mathrm{CaO}$

1. L

Zeolite

6.2

Other

1.0

Sludge/Frit ratio: $35 / 65$

Total Solids in Slurry: $41 \%$ 


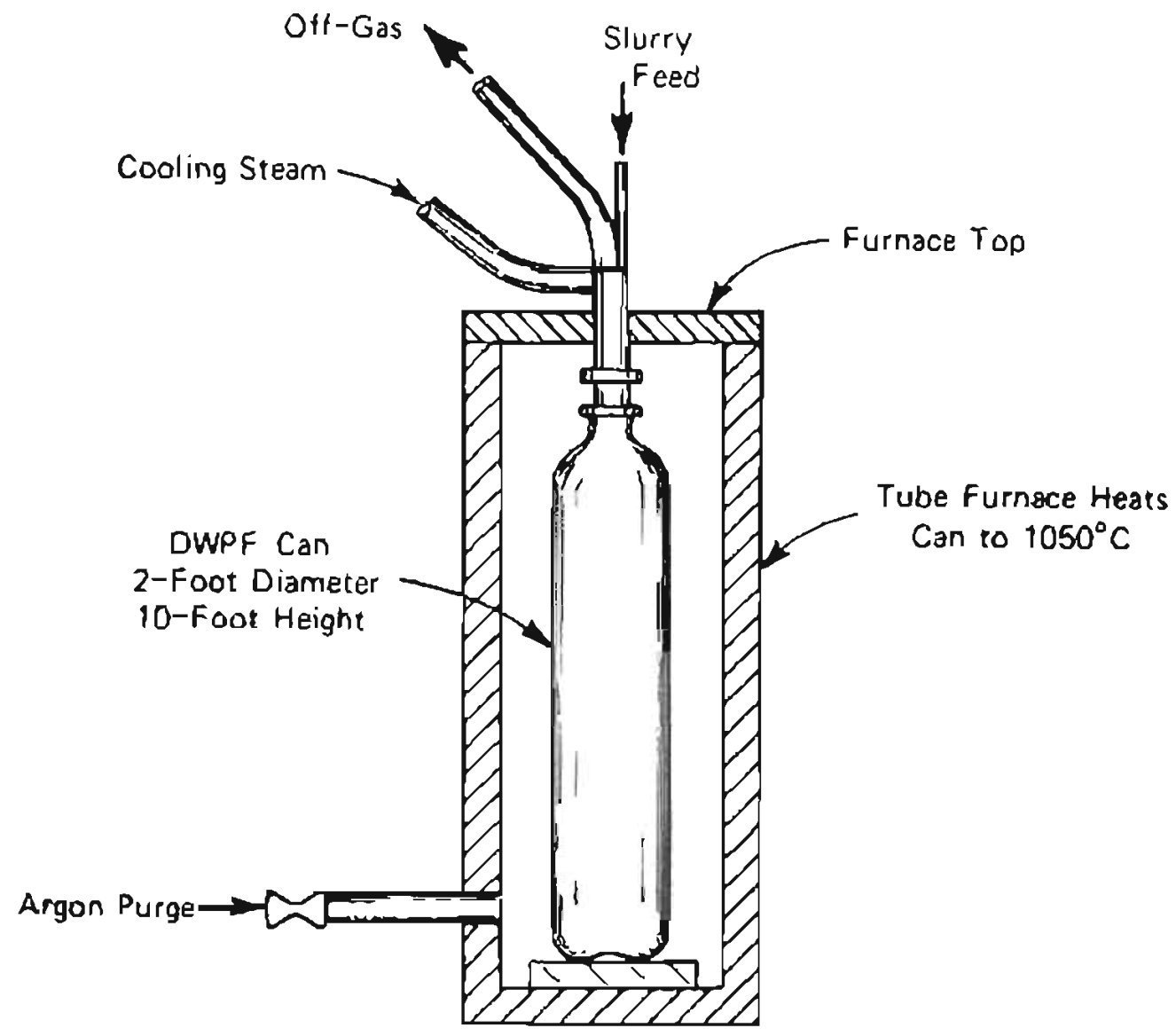

FIgURE 1. SICM Conceptusl Procesa 


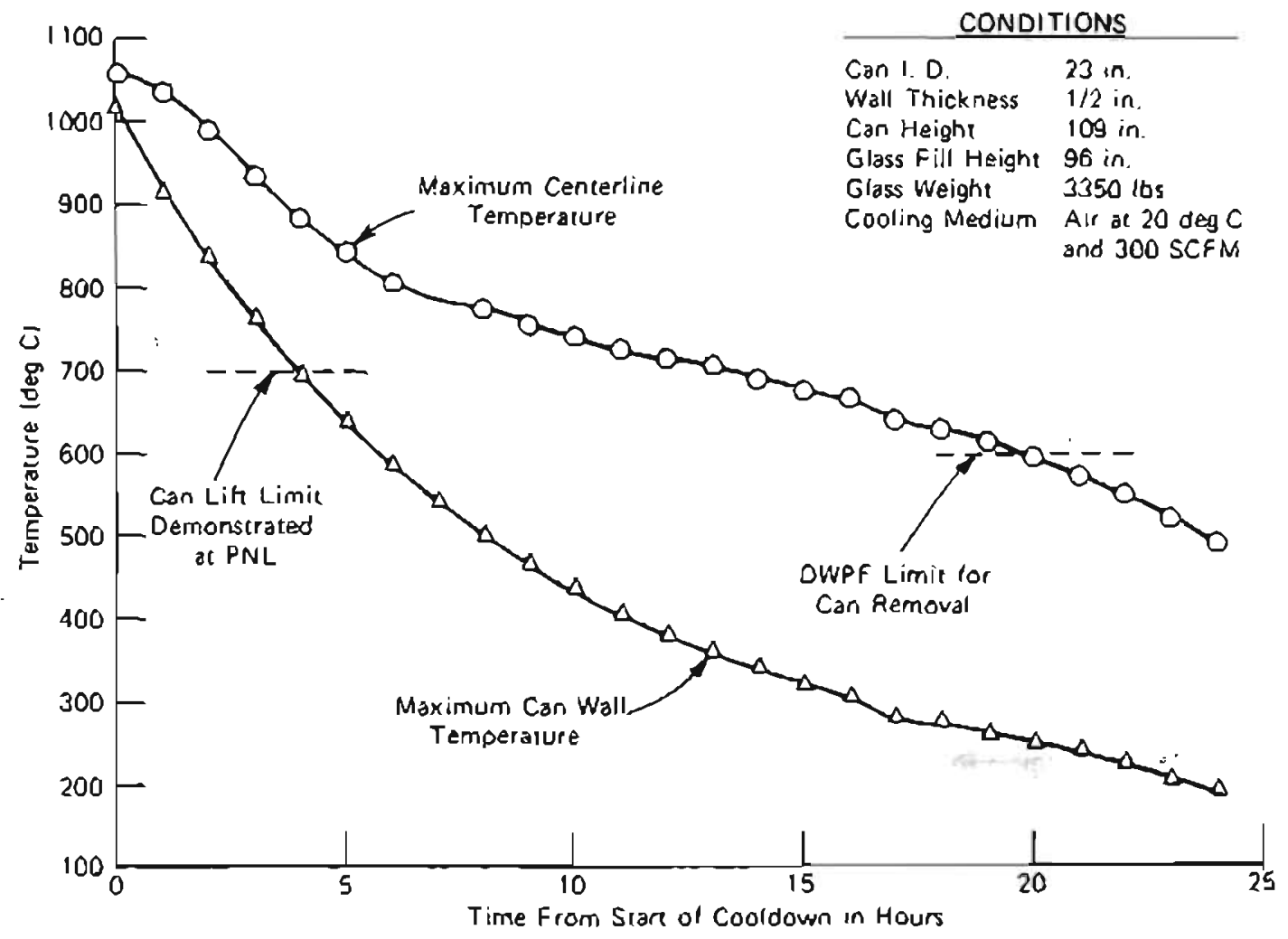

PIGUAE 2. Cooldow of a SICM Can 


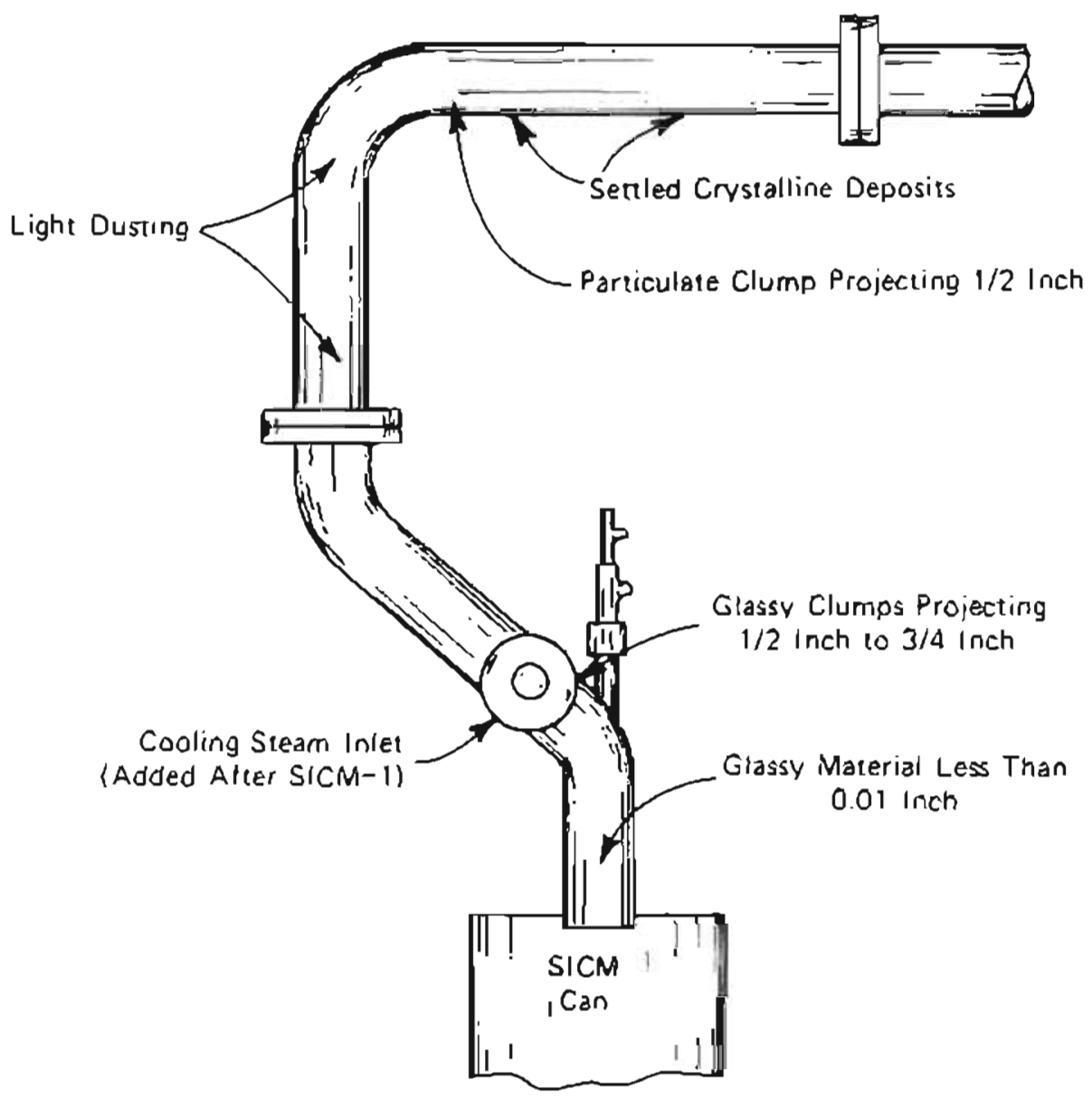

FIGURE 3. Off-Gas Deposita After SICM-1 


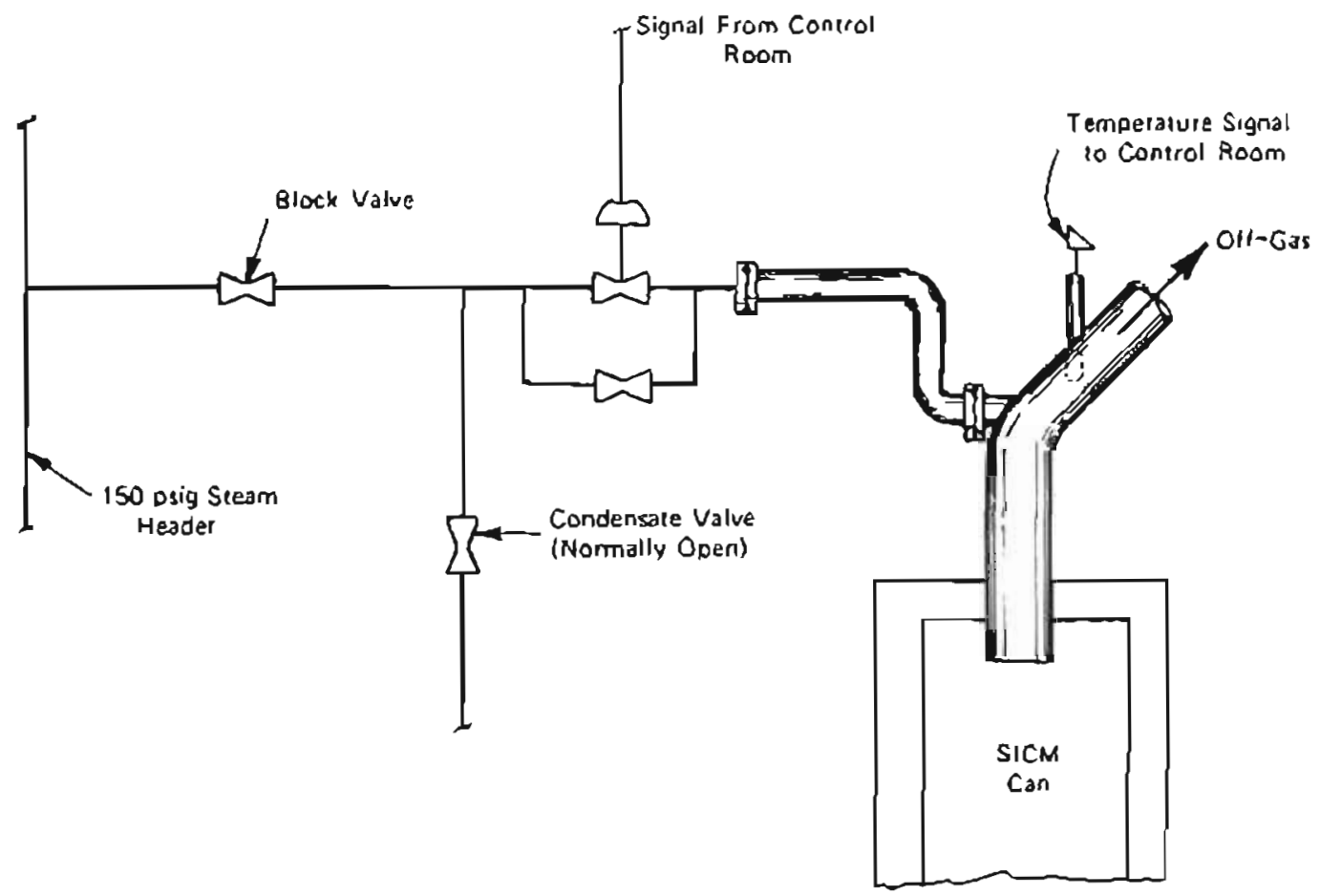

PIGURE 4. SICM Off-Gas Cooling Sgatel 


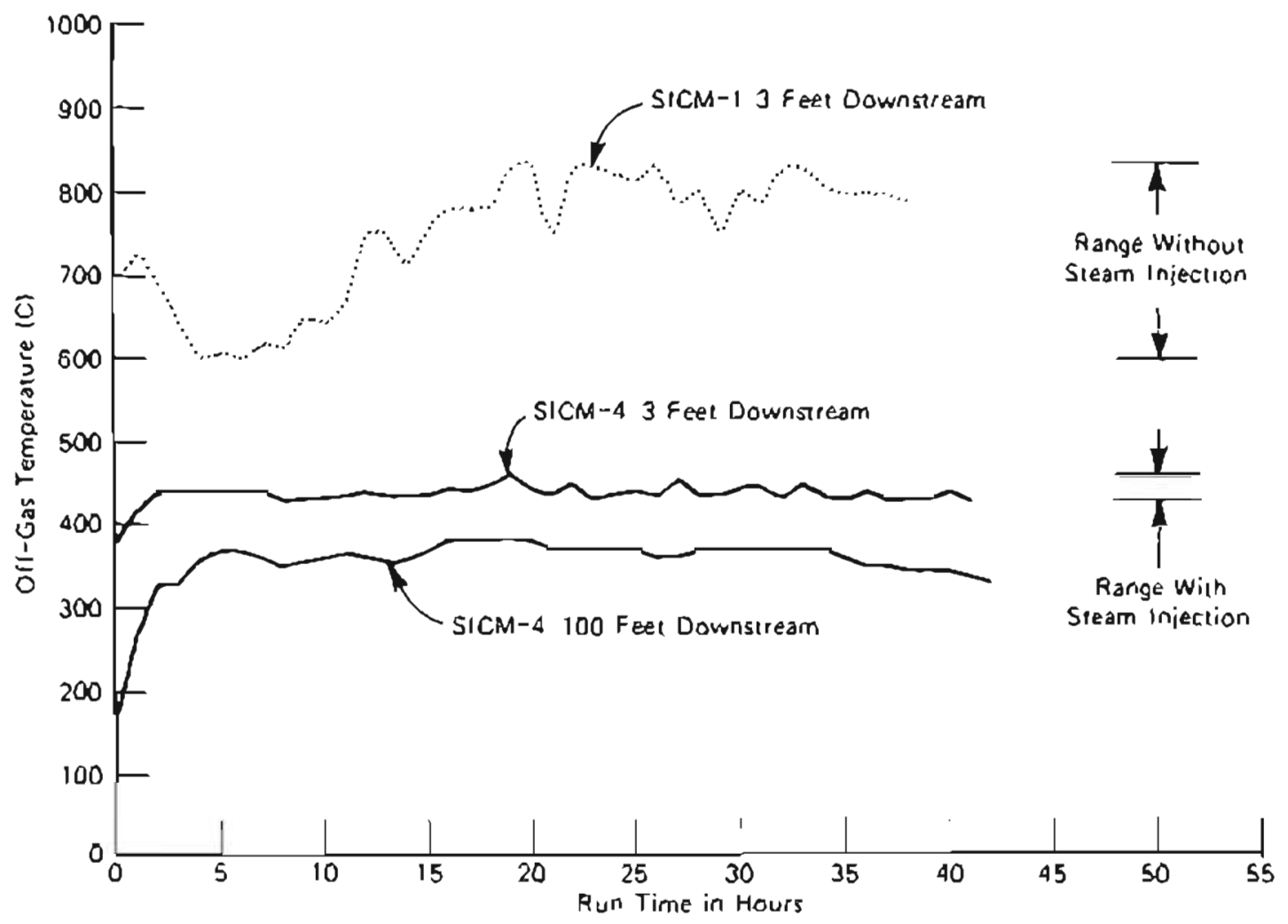

FIGURE 5. SICM Off-Gas Temperatures 


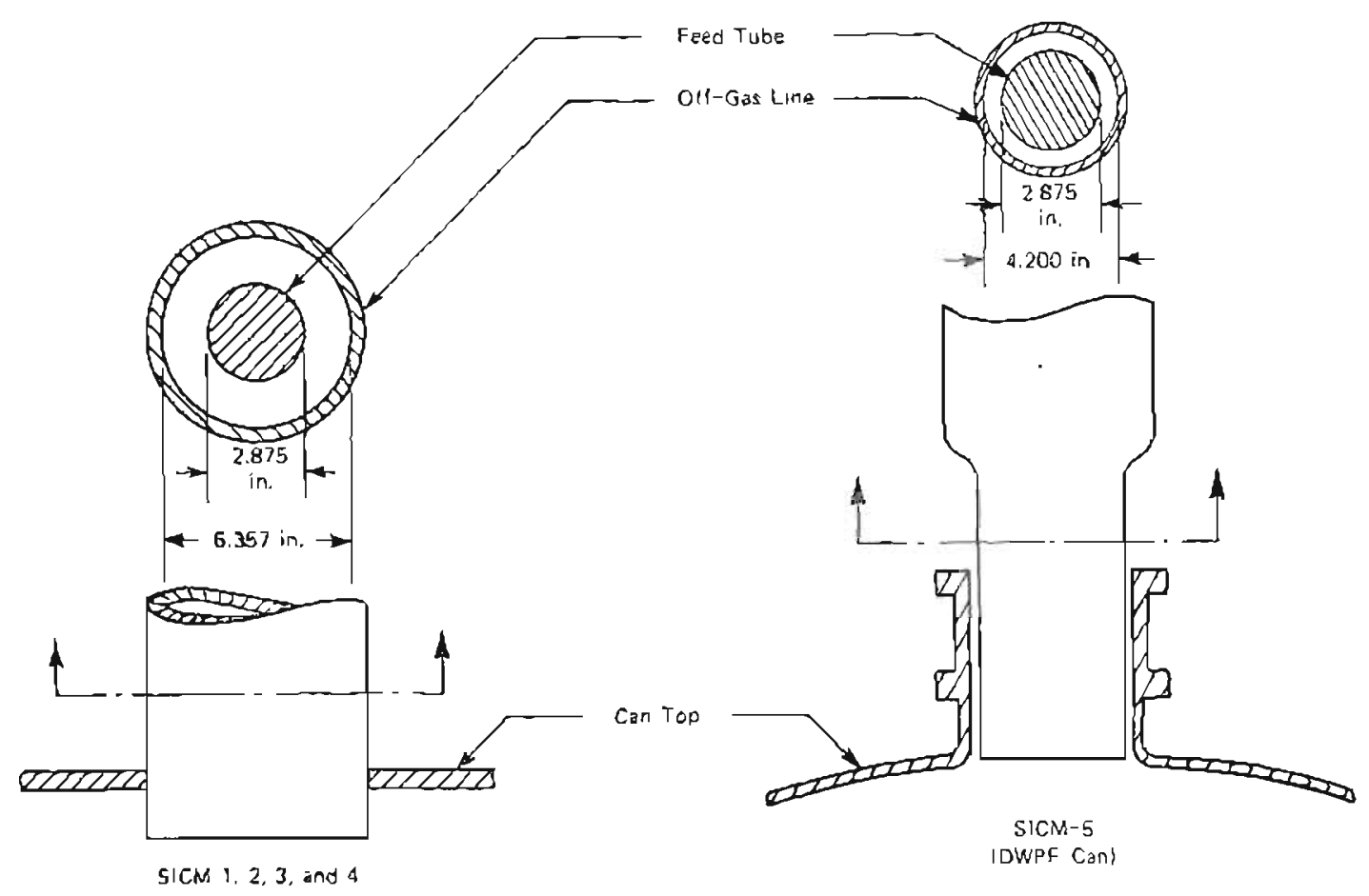

FIGURE 6. SICM-5 Modificstions 


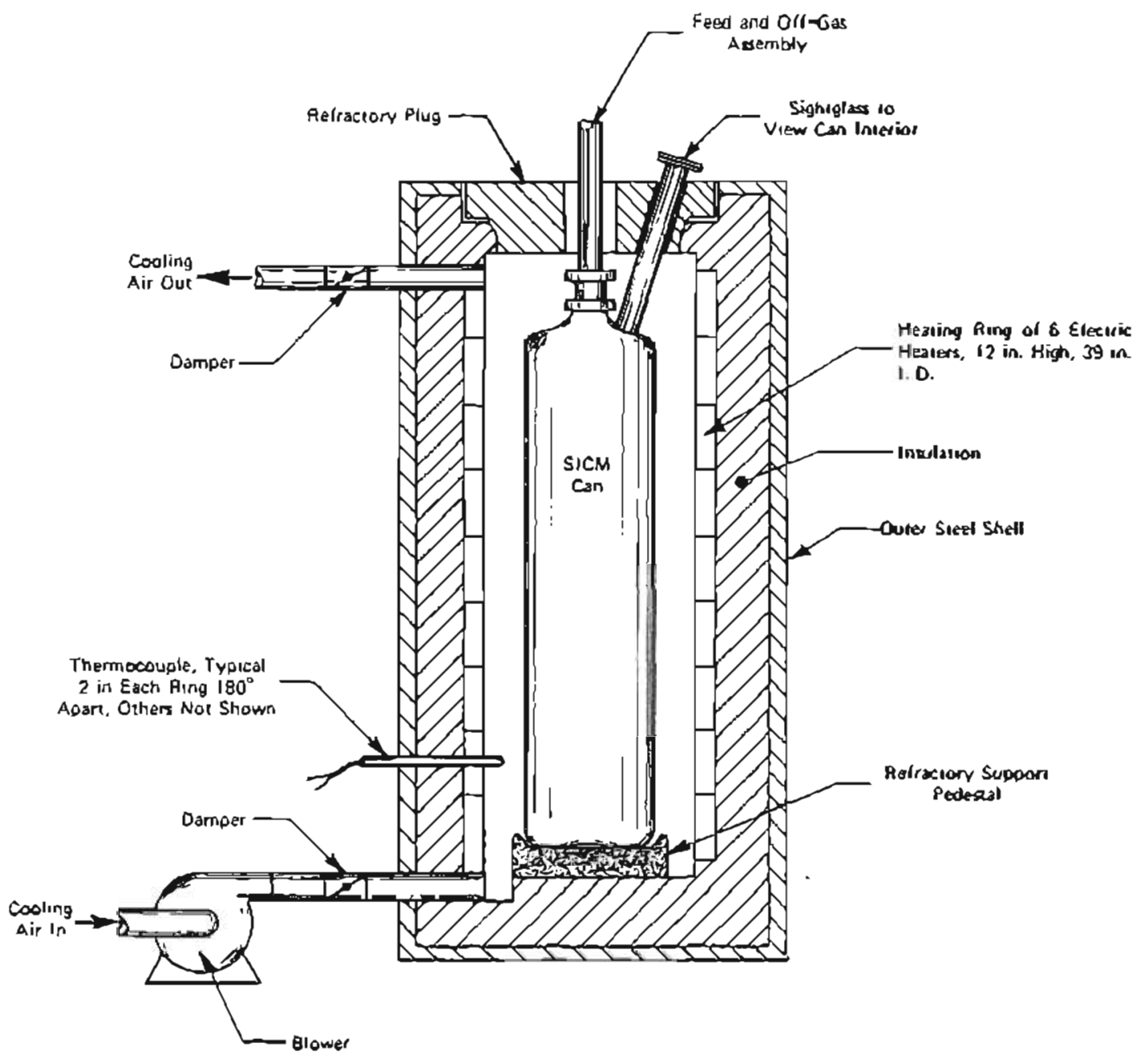

FIGURE 7. Furnace Uaed in SICM Experiments 


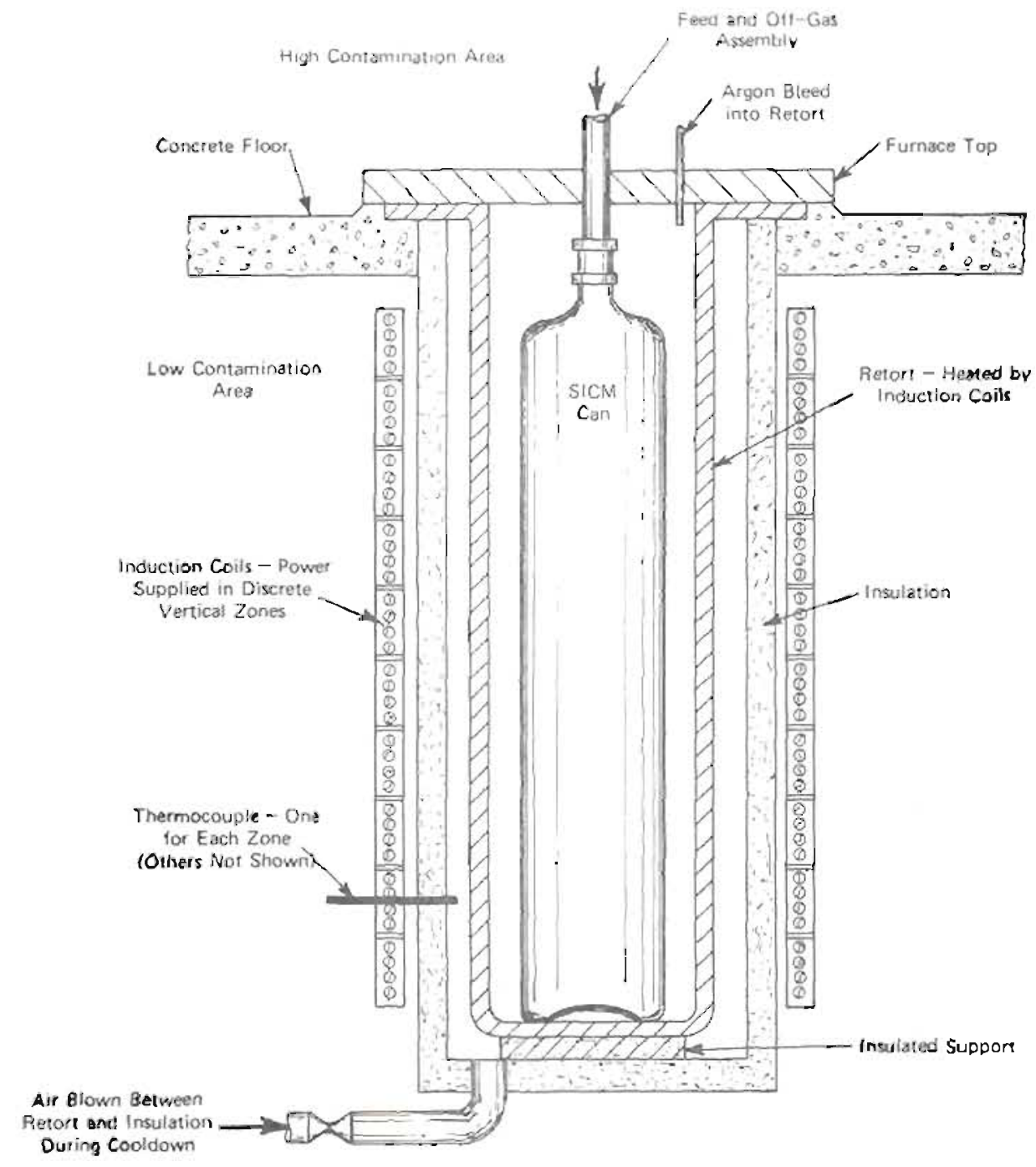

FIGURE 8. Furnace Conceptual Design 